\section{Influences on Faculty Willingness to Mentor Undergraduate Students from Another University as Part of an Interinstitutional Research Training Program}

\author{
Danielle X. Morales, ${ }^{*}$ Sara E. Grineski, and Timothy W. Collins
}

Department of Sociology and Anthropology, University of Texas at El Paso, El Paso, TX 79968

\begin{abstract}
In 2014, the National Institutes of Health invested $\$ 31$ million in 10 primary institutions across the United States through the Building Undergraduate Infrastructure Leading to Diversity (BUILD) program; one requirement of BUILD is sending undergraduate trainees from those primary institutions to partner institutions for research experiences. Mechanisms like BUILD are designed to broaden research opportunities for students, especially those from underrepresented backgrounds. However, to our knowledge, no studies have examined faculty willingness to mentor undergraduates from other institutions through structured training programs. Survey data from 536 faculty members at 13 institutions were collected in Fall 2013 and analyzed using multiple statistical techniques. Results show that faculty who valued the opportunity to increase diversity in the academy and those who believed that mentoring undergraduates benefited their own research expressed greater willingness to serve as research mentors to visiting undergraduates, and faculty who perceived that they did not have the ability to accommodate additional students expressed less willingness to do so. Most respondents viewed student and faculty incentives as motivating factors in their willingness to mentor, but their perspectives on different types of incentives varied based on faculty career stage, discipline, and research funding status. Results have important implications for designing multi-institutional undergraduate research training programs.
\end{abstract}

\section{INTRODUCTION}

Research with a faculty mentor is crucial for undergraduate student success (Volkwein and Carbone, 1994; Nagda et al., 1998; Tompkins, 1998; Kardash, 2000; Wasserman, 2000; Hathaway et al., 2002; Ishiyama, 2002; Bauer and Bennett, 2003, 2008; Lopatto, 2004; Seymour et al., 2004; Pike and Kuh, 2005; Hunter et al., 2007; Kuh et al., 2007; Cole and Espinoza, 2008; Russell, 2008; Laursen et al., 2010; Espinosa, 2011). The retention and success of underrepresented minority students in particular has been shown to be strongly related to faculty-mentored undergraduate research experiences (Cronan-Hillix et al., 1986; Hill et al., 1989; Luna and Cullen, 1995; Campbell and Campbell, 1997; Brown et al., 1999; Stromei, 2000; Hunter, 2002). However, all students do not have the same opportunities to take part in faculty-mentored research. In a national study, the American Association for Colleges and Universities found that underserved students (e.g., Hispanic and first-generation students) engaged in significantly fewer high-impact education practices, including undergraduate research, than their traditionally advantaged peers (e.g., white and non-first-generation students; Finley and McNair, 2013).
Pat Marsteller, Monitoring Editor

Submitted January 14, 2016; Revised April 19, 2016; Accepted May 13, 2016

CBE Life Sci Educ September 1, 2016 15:ar35 DOI:10.1187/cbe.16-01-0039

*Address correspondence to: Danielle X. Morales (xdeng2@utep.edu)

() 2016 D. X. Morales et al. CBE-Life Sciences Education () 2016 The American Society for Cell Biology. This article is distributed by The American Society for Cell Biology under license from the author(s). It is available to the public under an Attribution-Noncommercial-Share Alike 3.0 Unported Creative Commons License (http://creativecommons.org/licenses/ by-nc-sa/3.0).

"ASCB ${ }^{\circledR}$ " and "The American Society for Cell Biology $\circledR^{\prime \prime}$ are registered trademarks of The American Society for Cell Biology. 
Underserved and underrepresented minority students are missing out on faculty-mentored research opportunities because many of them are enrolled in resource-strapped institutions of higher education that lack personnel and monetary support for research. It is difficult for students attending low-resource institutions to find a research mentor, because there are fewer research-active faculty and, often, many part-time instructors. Clearly, increasing the numbers of underrepresented students who pursue advanced science, technology, engineering, and mathematics (STEM) degrees and enter research careers requires systematically expanding opportunities for students to engage in research with, and be mentored by, faculty who are external to their institutions. Therefore, interinstitutional research training programs are needed.

The need for these sorts of training programs has been recognized by funding agencies, and a growing number of U.S. institutions have been supported by the National Institutes of Health (NIH) and the National Science Foundation (NSF) to provide intensive, faculty-mentored summer research experiences to visiting students over the past $20 \mathrm{yr}$. For example, the Summer Undergraduate Research Experience (SURE) Program at Emory University, underwritten by the Howard Hughes Medical Institute and other funding partners, has been training undergraduate students for 25 yr. During their 10-wk summer program, SURE fellows live on the Emory campus and conduct full-time mentored research. They also receive training in multiple competencies and are provided opportunities to develop fundamental skills for success in research. Evaluations of summer research training programs indicate that interinstitutional programs serve as effective routes to research careers for undergraduate students (Frantz et al., 2006). Specifically, working with an external faculty mentor during the summer has positive impacts on students' levels of interest in, preparedness for, and actual pursuit of graduate study and professional careers in the sciences (Foertsch et al., 1997; Alexander et al., 2000; Schowen, 2002; Frantz et al., 2006; Gum et al., 2007). Additionally, summer research programs greatly improve students' research skills, knowledge, and research productivity (Kremer and Bringle, 1990; Kardash, 2000; Burnley et al., 2002; Zydney et al., 2002; Lopatto, 2004; Seymour et al., 2004; Gum et al., 2007; Butler et al., 2008). Overall, doing research in the summer is an intensive, enjoyable, and beneficial learning experience for most students (Alexander et al., 2000). Faculty mentors are critical to the success of summer research programs, because they function as role models for students, support and encourage students through individual mentoring relationships, and build students' confidence to pursue and persist in graduate degrees (Alexander et al., 2000). An open and congenial relationship with one's mentor and a good experience in his or her lab have been assessed by students as important factors in the success of summer research programs (Foertsch et al., 1997; Lopatto, 2004; Falconer and Holcomb, 2008). Therefore, student and programmatic success in undergraduate research initiatives can be directly linked to the ability of these programs to recruit and retain excellent faculty mentors (Zydney et al., 2002).

Given the direct influence faculty mentors have on students and the success of undergraduate research programs, it is important to study factors influencing faculty participation in interinstitutional research programs. Some empirical studies have examined faculty willingness to mentor undergraduate students (Eagan et al., 2011; Gates et al., 1999; Kardash, 2000; Merkel, 2001; Chopin, 2002; Johnson, 2002; Zydney et al., 2002; Prince et al., 2007; Webber et al., 2013). While important, those studies have limitations in terms of focusing only on faculty-student mentoring in the same institution. Among the few studies focused on external faculty mentors, researchers found that one of the key challenges many undergraduate summer research programs are facing is the recruitment of faculty members who are willing to mentor undergraduate students from other institutions (Frantz et al., 2006); and for some faculty, having enough time to take on additional summer students was the major obstacle in their ability to mentor external students (Foertsch et al., 1997). Although studies have suggested that program incentives-including faculty workload reductions, financial stipends, or credit toward promotion/tenure-might encourage faculty to mentor undergraduate students in general (Boyle and Boice, 1998; Dunham-Taylor et al., 2008; Zellers et al., 2008), none has compared different types of program incentives or examined characteristics influencing faculty preferences for incentives such as research funding status, career stage, or discipline. To inform the design of effective interinstitutional research training programs, more refined knowledge regarding factors influencing faculty willingness to mentor is needed.

This paper extends current knowledge by focusing on determinants of faculty willingness to mentor visiting undergraduate students via interinstitutional research training programs. Our interest is twofold. First, we seek to identify factors shaping faculty members' motivation to mentor undergraduates from other universities through a structured research training program. Second, we aim to clarify the types of incentives that faculty view as most important in their decision to mentor visiting undergraduate students, and how the importance of specific types of incentives varies based on faculty research funding, career stage, and discipline. We examine these three faculty characteristics, because we hypothesize that each influences the importance that faculty members ascribe to specific types of incentives and also because each is practically relevant to the design of interinstitutional research training programs that successfully recruit and adequately support faculty as mentors. Our analysis is based on results from a survey of faculty members conducted across 13 research universities that form part of the University of Texas at El Paso's (UTEP) NIH-funded BUILDing SCHOLARS network (http://buildingscholars.utep.edu).

\section{DATA AND METHODS}

The analyses presented in the paper answer two research questions:

1. Which factors predict faculty willingness to mentor undergraduate students from another university through an interinstitutional research training program?

2. Which incentives are faculty members most interested in receiving in order to accept a visiting undergraduate research mentee?

To answer research question 1 , we report results from a generalized linear model (GzLM) examining the influences of different factors on faculty motivation to mentor undergraduate students visiting from another university. With regard to 
research question 2, we conducted descriptive and bivariate analyses with a suite of variables related to types of incentives that an interinstitutional research training program could potentially offer to faculty mentors. In addition to describing preferences for incentives for the group of faculty under study, we examined differences in preferences for incentives based on faculty research funding, career stage, and discipline.

\section{Study Context: UTEP and Its BUILD program}

UTEP is one of the nation's leading contributors to diversity in higher education, specifically through the provision of educational opportunities for the rapidly growing, albeit socially and economically disadvantaged, U.S. Hispanic population. UTEP ranks second among all universities in the continental United States in conferring bachelor's degrees on Hispanics (UTEP CIERP, 2013). Washington Monthly's 2013 rankings place UTEP as the seventh-best U.S. university overall, which is largely attributable to UTEP's number one ranking in the "social mobility" category.

In 2014, the NIH invested $\$ 31$ million in 10 primary institutions across the United States through the Building Undergraduate Infrastructure Leading to Diversity (BUILD) program. As one of the primary institutions, UTEP is addressing the needs of students in the U.S. Southwest through a multi-institution consortium that includes Texas, New Mexico, and Arizona, states that are home to dense concentrations of Hispanic and Native American students. The consortium includes a network composed of one primary or lead institution (UTEP), seven pipeline partner institutions, and 12 research partner institutions (Table 1), all committed to the goal of training students from the region to enter the NIH-funded workforce. A major component of the BUILD awards involves the provision of summer research experiences at research partner institutions for students from the primary institutions and pipeline partner institutions, where cutting-edge faculty-mentored research opportunities are less readily available.

\section{The Survey and Data Collection}

A cross-sectional Institutional Review Board-approved structured survey was designed and administered using Qualtrics survey software. It was sent to faculty with health/biomedical research experience at research partner institutions (Table 1; see second column) and at the lead institution, UTEP. To create our sampling frame, we asked our primary contacts at each institution for a list of faculty members at their institutions who conducted health/biomedical research broadly defined. As a result, we identified 887 faculty members across the 13 institutions as potential participants. Before the launch of the survey, we sent a prenotification email to all identified faculty members to raise their awareness about the forthcoming study invitation. Two days after the prenotification email was sent, potential faculty participants received a personalized email invitation outlining the survey purpose, length, and contents; IRB information; and details about an incentive. For nonrespondents, follow-up emails requesting participation were sent weekly for three straight weeks. For those who completed the survey in its entirety, a \$10 gift card link was made accessible via a follow-up email. The survey was conducted in two rounds. The first round was open from mid-November through mid-December 2013 and included six institutions; the second round, which
TABLE 1. Pipeline and research partner institutions of UTEP's BUILD program

\begin{tabular}{ll}
\hline Pipeline partner institutions & Research partner institutions \\
\hline Western New Mexico University & Arizona State University \\
Northern New Mexico College & University of Arizona \\
New Mexico-IDeA Networks of & University of New Mexico \\
Biomedical Research Excellence & \\
(NM-INBRE) institutions & \\
Southwestern Indian Polytechnic & University of New Mexico Health \\
Institute & Sciences Center \\
Transmountain Early College High & Baylor College of Medicine \\
School (El Paso) & \\
El Paso Community College & Rice University \\
Texas Southern University & University of Texas at Arlington \\
& University of Texas at Austin \\
& University of Texas Health \\
& Sciences Center Houston \\
& University of Texas Southwestern \\
& Medical Center \\
& University of Connecticut \\
& Connecticut Institute for \\
& Clinical and Translational \\
& Science (CICATS) \\
& Clemson University \\
\hline
\end{tabular}

${ }^{\mathrm{a} E x t r a r e g i o n a l ~ p a r t n e r . ~}$

included another eight institutions, was open from mid-January through mid-February 2014. The response rate across all institutions was $61 \%$ (with a range of 42-100\%); a total of 541 individuals completed the survey.

\section{Variables}

Table 2 provides the coding scheme for all the variables used in the analyses. Table 3 provides descriptive statistics for each variable. Each variable is discussed in one of the following sections.

Dependent Variables. For research question 1, the dependent variable is a dichotomous measure constructed from a question that asked: "Would you be interested in mentoring an undergraduate BUILD scholar from another institution?" In the survey, BUILD scholars were described as an undergraduate student research assistant, likely from an underrepresented group, on a scholarship. Faculty could respond "yes" or "no." Approximately $74 \%$ of faculty in the sample reported being interested in mentoring an undergraduate BUILD scholar from another institution.

For research question 2, thirteen dependent variables were constructed by using responses to the survey prompt: "To accept an undergraduate student [for the summer] on your research team, what would you need at a bare minimum, what would you appreciate if money were less of an issue, and what would you not be interested in receiving?" Table 2 lists all the incentive items we used in the survey (e.g., stipends for students). Responses were rated on a three-point Likert scale $(0=$ "It would not motivate me"; 1 = "It would be a 'bonus' for me"; 2 = "It is a 'deal breaker' for me"). We developed these items based on our own knowledge of undergraduate research training programs and previous literature referencing incentives (Boyle and Boice, 1998; Dunham-Taylor et al., 2008; Zellers et al., 2008). 
TABLE 2. Description of variables and measures

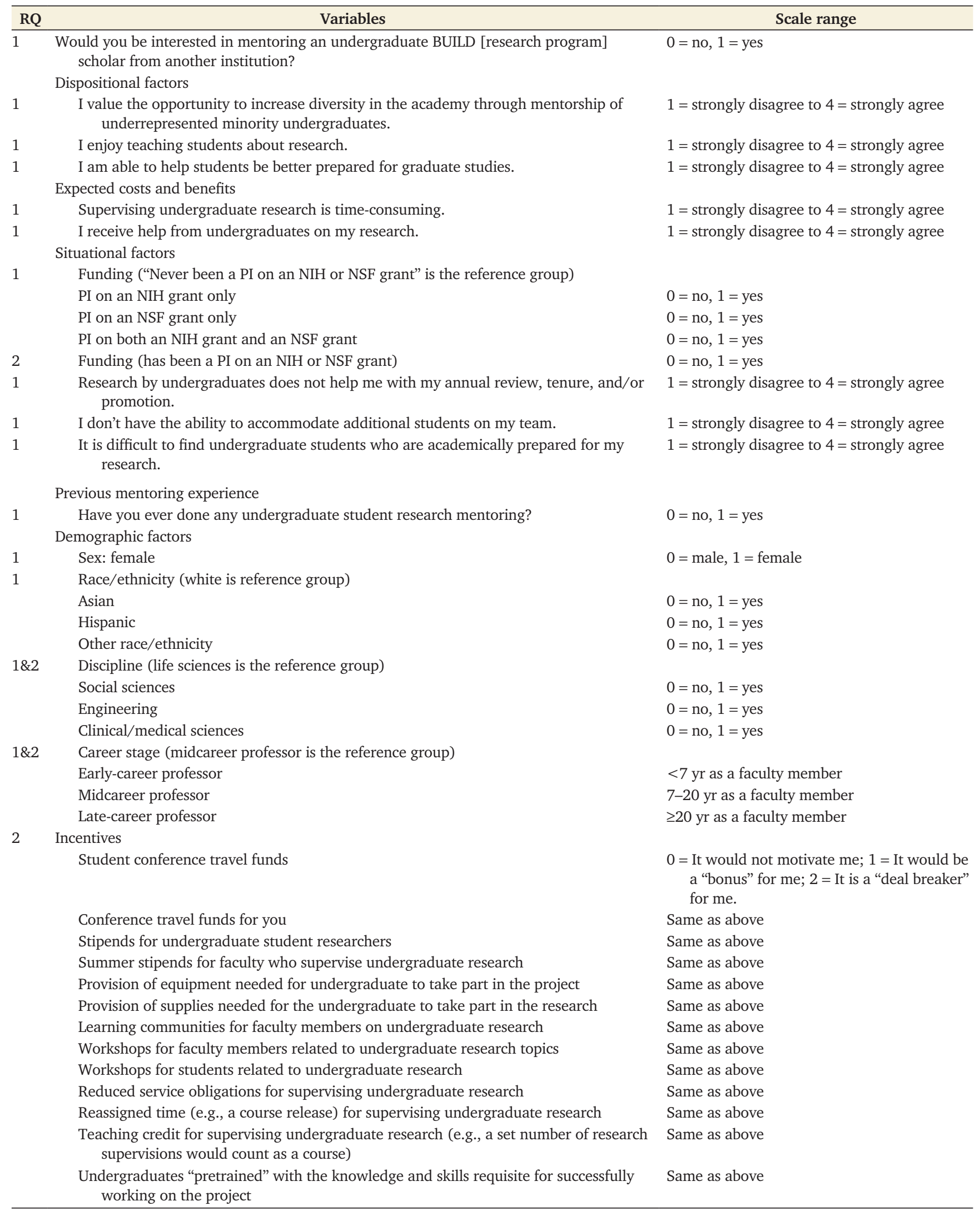


TABLE 3. Descriptive statistics for all analysis variables $(N=536)$

\begin{tabular}{|c|c|c|c|c|c|}
\hline Variables & & Frequency & Missing \% & Mean & SD \\
\hline \multicolumn{6}{|l|}{ Categorical variables } \\
\hline \multirow{2}{*}{$\begin{array}{l}\text { Would you be interested in mentoring an undergraduate BUILD } \\
\text { [research program] scholar from another institution? }\end{array}$} & No & 132 & 6.2 & 0.26 & \\
\hline & Yes & 371 & & 0.74 & \\
\hline \multirow[t]{2}{*}{ Sex } & Male & 267 & 14.2 & 0.58 & \\
\hline & Female & 193 & & 0.42 & \\
\hline \multirow[t]{4}{*}{ Race/ethnicity } & White & 370 & 0.0 & 0.69 & \\
\hline & Hispanic & 93 & & 0.17 & \\
\hline & Asian & 57 & & 0.11 & \\
\hline & Other & 16 & & 0.03 & \\
\hline \multirow[t]{4}{*}{ Discipline } & Life sciences & 166 & 0.0 & 0.31 & \\
\hline & Social sciences & 67 & & 0.12 & \\
\hline & Engineering & 43 & & 0.08 & \\
\hline & Clinical/medical sciences & 260 & & 0.49 & \\
\hline \multirow[t]{3}{*}{ Career stage } & Early career & 174 & 0.0 & 0.32 & \\
\hline & Midcareer & 191 & & 0.36 & \\
\hline & Late career & 171 & & 0.32 & \\
\hline \multirow[t]{2}{*}{ Previous mentoring experience } & No & 36 & 4.7 & 0.07 & \\
\hline & Yes & 475 & & 0.93 & \\
\hline \multirow[t]{5}{*}{ Funding } & No NIH or NSF funding & 168 & 0.0 & 0.31 & \\
\hline & Only NIH & 274 & & 0.51 & \\
\hline & Only NSF & 31 & & 0.06 & \\
\hline & Both NIH and NSF & 63 & & 0.12 & \\
\hline & $\mathrm{NIH}$ and/or NSF${ }^{\mathrm{a}}$ & 368 & & 0.69 & \\
\hline \multicolumn{6}{|l|}{ Continuous variables } \\
\hline $\begin{array}{l}\text { I value the opportunity to increase diversity in the academy through } \\
\text { mentorship of underrepresented minority undergraduates. }\end{array}$ & & & 16.2 & 3.55 & 0.59 \\
\hline I enjoy teaching students about research. & & & 14.6 & 3.61 & 0.53 \\
\hline I am able to help students be better prepared for graduate studies. & & & 14.2 & 3.62 & 0.50 \\
\hline $\begin{array}{l}\text { Research by undergraduates does not help me with my annual } \\
\text { review, tenure, and/or promotion. }\end{array}$ & & & 15.3 & 2.47 & 0.83 \\
\hline $\begin{array}{l}\text { I don't have the ability to accommodate additional students on my } \\
\text { team. }\end{array}$ & & & 11.6 & 2.34 & 0.75 \\
\hline $\begin{array}{l}\text { It is difficult to find undergraduate students who are academically } \\
\text { prepared for my research. }\end{array}$ & & & 9.3 & 2.53 & 0.84 \\
\hline Supervising undergraduate research is time-consuming. & & & 8.6 & 3.24 & 0.68 \\
\hline I receive help from undergraduates on my research. & & & 15.3 & 3.00 & 0.74 \\
\hline \multicolumn{6}{|l|}{ Incentives } \\
\hline Student conference travel funds & & & 9.0 & 0.76 & 0.55 \\
\hline Conference travel funds for you & & & 9.3 & 0.74 & 0.55 \\
\hline Stipends for undergraduate student researchers & & & 9.7 & 1.38 & 0.57 \\
\hline Summer stipends for faculty who supervise undergraduate research & & & 9.5 & 0.98 & 0.61 \\
\hline $\begin{array}{l}\text { Provision of equipment needed for undergraduate to take part in the } \\
\text { project }\end{array}$ & & & 9.9 & 0.79 & 0.64 \\
\hline $\begin{array}{l}\text { Provision of supplies needed for the undergraduate to take part in } \\
\text { the research }\end{array}$ & & & 9.9 & 1.00 & 0.63 \\
\hline $\begin{array}{l}\text { Learning communities for faculty members on undergraduate } \\
\text { research }\end{array}$ & & & 9.9 & 0.34 & 0.54 \\
\hline $\begin{array}{l}\text { Workshops for faculty members related to undergraduate research } \\
\text { topics }\end{array}$ & & & 9.9 & 0.35 & 0.55 \\
\hline Workshops for students related to undergraduate research & & & 9.7 & 0.75 & 0.61 \\
\hline Reduced service obligations for supervising undergraduate research & & & 9.9 & 0.71 & 0.63 \\
\hline $\begin{array}{l}\text { Reassigned time (e.g., a course release) for supervising } \\
\text { undergraduate research }\end{array}$ & & & 10.3 & 0.73 & 0.65 \\
\hline $\begin{array}{l}\text { Teaching credit for supervising undergraduate research (e.g., a set } \\
\text { number of research supervisions would count as a course) }\end{array}$ & & & 10.1 & 0.89 & 0.63 \\
\hline $\begin{array}{l}\text { Undergraduates "pretrained" with the knowledge and skills requisite } \\
\text { for successfully working on the project }\end{array}$ & & & 9.9 & 1.01 & 0.56 \\
\hline
\end{tabular}

${ }^{a}$ Used only in research question 2 . 
Independent Variables. The independent variables for the first research question were grouped into five factors. The five factors map to Allen's (2007) five influences on motivation to mentor, which he derived from literature on the corporate world and we adapt to a higher education context focused on faculty motivation to mentor undergraduate students. The five important influences on the motivation to mentor are organizational citizenship behavior, expected costs and benefits, situational factors, previous mentoring experience, and demographic factors (Allen, 2007).

Organizational Citizenship Behavior. Research has suggested that mentoring others can be viewed as a specific form of organizational citizenship behavior (Allen, 2003). Organizational citizenship behavior was defined as "exerting more effort on the job than is required or expected by formal role prescriptions" (McManus and Russell, 1997, p. 148). Findings from studies on faculty members' motivation to mentor students align with the organizational citizenship framework in that having a positive attitude regarding the work (e.g., undergraduate education or undergraduate research) increases employees' (or faculty's) likelihood of assuming responsibilities outside of their prescribed duties (mentoring students; McManus and Russell, 1997; Judge et al., 2001; Eagan et al., 2011; Webber et al., 2013). Three separate variables were constructed to operationalize organizational citizenship behavior using responses to the survey prompt: "Please rate the extent to which the following items are benefits that you receive from working with undergraduate students on research projects." We used responses to the following three items when constructing the three variables: 1) "I value the opportunity to increase diversity in the academy through mentorship of underrepresented minority undergraduates." 2) "I enjoy teaching students about research." 3) "I am able to help students be better prepared for graduate studies." The three items were rated on a four-point Likert scale ( $1=$ strongly disagree to $4=$ strongly agree), and the analysis variables were untransformed.

Expected Costs and Benefits. Costs and benefits have been shown to be important in mentoring studies utilizing social exchange theory (Gibb, 1999; Hegstad, 1999; Eagan et al., 2011; Webber et al., 2013). Social exchange theory suggests that individuals choose to engage in relationships that they expect to offer beneficial personal outcomes (Emerson, 1981; Lawler and Thye, 1999). To operationalize the costs and benefits of mentoring undergraduates in research, we used survey items prefaced with the statement: "Please rate the extent to which the following items are barriers that you face in including undergraduate students in your research projects." For the variable "help on research," we used responses to the item: "I receive help from undergraduates on my research." To construct the variable "time," we used responses to the item: "Supervising undergraduate research is time-consuming." Both variables were rated on a four-point Likert scale ( 1 = strongly disagree to 4 = strongly agree).

Situational Factors. Besides organizational citizenship behavior and expected costs/benefits, motivation to mentor others can also be influenced by situational or contextual factors. Important situational factors include institutional reward sys- tems, opportunities for interactions, and monetary resources (Aryee et al., 1996; Allen et al., 2000; Einarson and Clarkberg, 2004; Eagan et al., 2011). Four variables were constructed to measure the three situational factors. Institutional rewards were measured by the variable 1) "tenure and/or promotion system." Opportunities for interactions were measured by 2) "lack of academically prepared undergraduates" and 3) "lack of ability to accommodate undergraduates." Monetary resources were measured by 4) "funding." To construct the first three variables, we used responses to survey items prefaced with the statement: "Please rate the extent to which the following items are barriers that you face in including undergraduate students in your research projects." We used responses to the following three survey items: 1) "Research by undergraduates does not help me with my annual review, tenure, and/or promotion." 2) "I do not have the ability to accommodate additional students on my team." 3) "It is difficult to find undergraduate students who are academically prepared for my research." Responses were rated on a four-point Likert scale ( 1 = strongly disagree to 4 = strongly agree). In addition, the 4) "funding" variable was constructed using yes/no responses to two questions: "Have you ever been a PI on an NIH grant?" and "Have you ever been a PI [principal investigator] on an NSF grant?" For research question 1, responses to these were recoded into a variable with four categories (each coded $0=$ no or 1 = yes): 1) had never been a PI on an NIH grant or an NSF grant; 2) had been a PI on an NIH grant; 3) had been a PI on an NSF grant; 4) had been a PI on both an NIH grant and an NSF grant. The reference group included those who had never been a PI on an NIH or an NSF grant.

Previous Mentoring Experience. Previous experience as a mentor and as a mentee both positively relate to motivation to mentor others (Ragins and Cotton, 1993; Ragins and Scandura, 1999; Allen, 2003; Allen et al., 1997, 2000; Bozionelos, 2004). We used the following survey question to construct a previous mentoring experience variable: "Have you ever done any undergraduate student research mentoring?" Responses were coded as $0=$ no or $1=$ yes.

Demographic Factors. Prior research has suggested there may be differences in faculty mentorship by demographic characteristics (Bellas and Toutkoushian, 1999; Antonio, 2002; Aagaard and Hauer, 2003; Eagan et al., 2011; Webber et al., 2013). Additionally, career-stage models suggest that motivation to mentor others is strongest at midcareer (Dalton et al., 1977; Levinson, 1978). We constructed variables measuring four demographic characteristics: sex, race, discipline, and career stage. To construct the race variable, we used two survey questions: "What is your race?" and "Are you of Hispanic, Latino, or Spanish origin?" The cell sizes for blacks (2\% of sample), Native Americans ( $1 \%$ of sample), and others ( $1 \%$ ) were too small to analyze separately. Thus, we recoded the data into four mutually exclusive categories (each coded $0=$ no or $1=$ yes): Asian (non-Hispanic; 11\%), Hispanic (17\%), and Other (which includes black, Native American, and others; all are nonwhite and non-Hispanic; 3\%), using the reference group of white (non-Hispanic; 69\%). We also analyze two variables that measure additional faculty characteristics. While we did not ask directly for faculty members' disciplines in the survey, we were 
able to cross-reference this item using an Internet search. We categorized all respondents into four broad disciplinary groups (each coded $0=$ no or $1=$ yes): life sciences (reference group), social sciences, engineering, and clinical/medical sciences. The discipline variable was also used for research question 2 . We measured career stage using responses to the question: "How many years of experience do you have in higher education as a faculty member?" Responses were recoded into three categories: early-career faculty ( $0-7 \mathrm{yr})$; midcareer faculty (7-20 yr); and late-career faculty (more than $20 \mathrm{yr}$ ). Midcareer faculty was used as the reference group.

Three independent variables-funding, career stage, and discipline-were used to answer research question 2 . Responses to the funding questions were recoded into a dichotomous variable $(0=$ had never been a PI on an NIH/NSF grant or $1=$ had been a PI on an NIH and/or NSF grant). For career stage and discipline, we used the same variables as in research question 1.

\section{Analyses}

We began our research question 1 analysis by first seeking to reduce the effects of nonresponse bias. We excluded cases with a relatively high proportion of missing data (i.e., more than $50 \%$ missing for the variables included in the analysis), which resulted in the loss of 22 cases for an $N$ of 514 . We did not exclude these 22 cases for research question 2 , because the missing variables did not affect our analysis for that question. Table 3 shows that the percent missing for the variables ranged from 0 to $16 \%$. The missing values of all variables used in the GzLM were multiply imputed. Multiple imputation (MI) involves creating multiple sets of values for missing observations using a regression-based approach and is currently considered a best practice for addressing missing data in statistical analysis. MI is used to avoid the bias that can occur when missing values are not missing completely at random and is appropriate for self-reported survey data (Enders, 2010). Using IBM SPSS, version 22, statistical software, 20 imputed data sets were specified to increase power and 200 between-imputation iterations were used to ensure that the resulting imputations were independent of one another (Enders, 2010). The use of 20 data sets is recommended in $\mathrm{MI}$, as it maximizes power and improves the validity of multiparameter significance tests (Enders, 2010). We analyzed all independent variables based on ordinal measures (derived from survey responses to Likerttype scales) as continuous predictors for research question 1 . This approach is considered a best practice in MI when imputing missing data and estimating model parameters, since rounding off imputed values based on discrete categorical specifications has been shown to produce more biased parameter estimates in analysis models (Horton et al., 2003; Allison, 2005; Enders, 2010; Rodwell et al., 2014).

Following Eagan and colleagues (2011), we initially built a hierarchical generalized linear model (HGLM) to answer the first research question. HGLM is the most appropriate statistical technique to use when analyzing multilevel (i.e., clustered) data to predict a dichotomous outcome (Raudenbush and Bryk, 2002). Unlike Eagan et al. (2011), the results from the fully unconditional HGLM indicated that we did not need to use a multilevel model, since the outcome (i.e., willingness to mentor) did not significantly vary across the 13 institutions. Therefore, we proceeded with building a GzLM to examine relation- ships between the independent variables and the dependent variable at only the faculty level. In contrast to linear regression models, which assume normally distributed dependent variables, a GzLM supports analysis of nonnormal distributions and multiple link functions (Nelder and Wedderburn, 1972).

Given that the dependent variable is a dichotomous variable, we selected the binomial distribution for the GzLM. To select the best-fitting GzLM, we compared model fit when using different link functions appropriate for binomial distributions and for our dependent variable (i.e., logit link, complementary log-log link, and probit link), using the Akaike information criterion (AIC; Garson, 2012). We report results from the GzLM using a binomial distribution with logit link as the final model, because it had the lowest AIC value. We tested for possible multicollinearity among the analysis variables. According to variance inflation factor, tolerance, and condition index criteria (Belsley et al., 1980), inferences from GzLM results were not affected by multicollinearity problems.

To answer research question 2 , we first describe the most important incentives for the faculty as a whole group. Then we characterize differences between faculty who had been a PI on an NIH/NSF grant and faculty who had never been an PI on an $\mathrm{NIH} / \mathrm{NSF}$ grant in terms of their interests in receiving incentives from an interinstitutional research training program. Mann-Whitney $U$-tests were used to compare means from the two groups. Further, to examine whether faculty responses on the 13 incentive/benefit items differed based on faculty career stage or discipline, Kruskal-Wallis $H$ tests (one-way analysis of variance on ranks) were used to determine whether there were significant differences among the different groups (i.e., early-career faculty, midcareer faculty, and late-career faculty). We also used post hoc Mann-Whitney $U$-tests to compare each pair. We used original (nonimputed) data in the research question 2 analyses, because SPSS does not report pooled results from Mann-Whitney $U$-tests or Kruskal-Wallis $H$ tests.

\section{RESULTS}

\section{Research Question 1: Which Factors Predict Faculty Willingness to Mentor Undergraduate Students from Another University through an Interinstitutional Research Training Program?}

We present the results of the GzLM in Table 4. Considering variables related to organizational citizenship behavior, faculty who placed greater value on the opportunity to increase diversity in the academy through mentorship of underrepresented minorities had a significantly ( $p=0.024)$ higher probability of mentoring undergraduate students from another university through this undergraduate research program. In contrast, we found that faculty who agreed more strongly that they enjoyed teaching students about research and who believed more strongly that undergraduate research helps students prepare for graduate school were not significantly more likely to be interested in mentoring a student from another university through this program.

With regard to expected costs and benefits, the benefit finding was highly significant $(p=0.006)$, and the cost finding approached significance $(p=0.077)$, with both associations going in the expected direction. Faculty who agreed more strongly that they could receive help from undergraduates on their research had a significantly higher probability of being interested in this interinstitutional research training 
TABLE 4. Generalized linear model using a binomial distribution with a logit link function predicting faculty's motivation to mentor undergraduate students from another university in undergraduate research programs $(N=514)$

\begin{tabular}{|c|c|c|c|}
\hline & Odds ratio & SE & $p$ \\
\hline \multicolumn{4}{|l|}{ Dispositional factors } \\
\hline $\begin{array}{l}\text { I value the opportunity to increase diversity in the academy through mentorship of underrepresented } \\
\text { minority undergraduates. }\end{array}$ & $1.82 * *$ & 0.27 & 0.024 \\
\hline I enjoy teaching students about research. & 1.24 & 0.30 & 0.480 \\
\hline I am able to help students be better prepared for graduate studies. & 0.96 & 0.31 & 0.880 \\
\hline \multicolumn{4}{|l|}{ Expected costs and benefits } \\
\hline \multicolumn{4}{|l|}{ Situational factors } \\
\hline \multicolumn{4}{|l|}{ Funding/grant ("Never been a PI on an NIH/NSF grant" is the reference group) } \\
\hline PI on an NIH grant only & 0.94 & 0.30 & 0.832 \\
\hline PI on an NSF grant only & 0.68 & 0.53 & 0.462 \\
\hline PI on both an NIH grant and an NSF grant & $4.97 * *$ & 0.55 & 0.004 \\
\hline Have you ever done any undergraduate student research mentoring? & $2.73 *$ & 0.60 & 0.095 \\
\hline \multicolumn{4}{|l|}{ Demographic factors } \\
\hline Sex: female & 0.74 & 0.26 & 0.233 \\
\hline \multicolumn{4}{|l|}{ Race/ethnicity (white is the reference group) } \\
\hline Asian & $0.49 *$ & 0.38 & 0.067 \\
\hline Hispanic & 1.20 & 0.34 & 0.593 \\
\hline Other race/ethnicity & 0.65 & 0.65 & 0.518 \\
\hline \multicolumn{4}{|l|}{ Discipline (life sciences is the reference group) } \\
\hline Social sciences & 0.85 & 0.41 & 0.697 \\
\hline Engineering & 1.35 & 0.56 & 0.588 \\
\hline Clinical/medical sciences & 1.34 & 0.28 & 0.283 \\
\hline
\end{tabular}

$* p<0.10$.

$* * p<0.05$.

program, while those who agreed more strongly that mentoring undergraduate students was time-consuming had a lower probability of being interested in mentoring external undergraduate students.

Results for situational factors were mixed. Faculty who agreed strongly that they did not have the ability to accommodate additional students had a significantly $(p=0.023)$ lower probability of mentoring external students through this undergraduate research program. In terms of directionality, faculty members who agreed more strongly that mentoring undergraduates would not help with the annual review, tenure, and/or promotion had a higher probability $(p=0.098)$ of mentoring students from another university. The lack of academically prepared students did not approach significance as a predictor of mentoring interest. In terms of monetary resources, we found that faculty who had been a PI on both an NIH grant and an NSF grant were nearly five times more likely ( $p=$ 0.004 ) to be interested in mentoring students from another university through this program compared with faculty who had never been a PI on an NIH or NSF grant. Faculty who had been a PI on an NIH grant only or a PI on an NSF grant only had higher probabilities of being interested in mentoring students from another university compared with faculty who had never been a PI on an NIH or an NSF grant, but neither result approached statistical significance $(p=0.932$ and $p=0.620$, respectively). Previous mentoring experience was not a significant predictor in the model. However, the coefficient was positive, as expected.

In terms of the four demographic characteristics (sex, race/ ethnicity, discipline, and career stage), only the career-stage results were significant. Results indicate that, compared with midcareer faculty, late-career faculty $(p<0.001)$ and early-career faculty ( $p=0.016$ ) were 0.24 and 0.48 times less likely, respectively, to be interested in mentoring visiting students in this interinstitutional undergraduate research program than were midcareer faculty. Asian faculty had a lower probability of mentoring undergraduate students from another university ( $p$ $=0.067$ ) than did white (non-Hispanic) faculty. The other demographic variables did not approach statistical significance. In terms of directionality, Hispanic faculty were more likely to be interested in mentoring students from another university through this program than were white (non-Hispanic) faculty 
TABLE 5. Faculty responses to the incentive items

\begin{tabular}{|c|c|c|c|c|}
\hline Incentive items & $n$ & $\begin{array}{l}\text { It is a "deal } \\
\text { breaker" for me }\end{array}$ & $\begin{array}{l}\text { It would be a } \\
\text { "bonus" for me }\end{array}$ & $\begin{array}{l}\text { It would not } \\
\text { motivate me }\end{array}$ \\
\hline Student conference travel funds & 488 & $5.7 \%$ & $64.5 \%$ & $29.7 \%$ \\
\hline Conference travel funds for you & 486 & $5.6 \%$ & $63.0 \%$ & $31.5 \%$ \\
\hline Stipends for undergraduate student researchers & 484 & $42.4 \%$ & $53.1 \%$ & $4.5 \%$ \\
\hline Summer stipends for faculty who supervise undergraduate research & 485 & $17.7 \%$ & $62.5 \%$ & $19.8 \%$ \\
\hline Provision of equipment needed for undergraduate to take part in the project & 483 & $12.0 \%$ & $54.9 \%$ & $33.1 \%$ \\
\hline Provision of supplies needed for the undergraduate to take part in the research & 483 & $19.7 \%$ & $60.7 \%$ & $19.7 \%$ \\
\hline Learning communities for faculty members on undergraduate research & 483 & $3.5 \%$ & $27.1 \%$ & $69.4 \%$ \\
\hline Workshops for faculty members related to undergraduate research topics & 483 & $3.5 \%$ & $27.5 \%$ & $68.9 \%$ \\
\hline Workshops for students related to undergraduate research & 484 & $9.1 \%$ & $56.8 \%$ & $34.1 \%$ \\
\hline Reduced service obligations for supervising undergraduate research & 483 & $9.3 \%$ & $52.4 \%$ & $38.3 \%$ \\
\hline Reassigned time (e.g., a course release) for supervising undergraduate research & 481 & $11.0 \%$ & $50.5 \%$ & $38.5 \%$ \\
\hline $\begin{array}{l}\text { Teaching credit for supervising undergraduate research (e.g., a set number of } \\
\text { research supervisions would count as a course) }\end{array}$ & 482 & $15.1 \%$ & $58.9 \%$ & $25.9 \%$ \\
\hline $\begin{array}{l}\text { Undergraduates "pretrained" with the knowledge and skills requisite for } \\
\text { successfully working on the project }\end{array}$ & 483 & $16.1 \%$ & $68.3 \%$ & $15.5 \%$ \\
\hline
\end{tabular}

members. Social sciences faculty were less likely, and engineering and clinical/medical faculty more likely, than life sciences faculty to be interested in mentoring through this interinstitutional undergraduate research program.

\section{Research Question 2: Which Incentives Are Faculty Members Most Interested in Receiving in Order to Accept a Visiting Undergraduate Research Mentee?}

Table 5 presents percentages of faculty responses across the 13 incentives. Among them, stipends for undergraduate student researchers was the most popular incentive. More than $42 \%$ of respondents rated it as "deal breaker" and would need it to accept students from another university on their research teams. Other benefits faculty were highly interested in included provision of supplies needed for the undergraduate to take part in the research (19.7\% deal breaker), summer stipends for faculty who supervise undergraduate research $(17.7 \%$ deal breaker), undergraduates "pretrained" with the knowledge and skills requisite for successfully working on the project $(16.1 \%$ deal breaker), teaching credit for supervising undergraduate research (15.1\% deal breaker), and provision of equipment needed for the undergraduate to take part in the project $(12.0 \%$ deal breaker). Compared with other potential incentives, learning communities for faculty members on undergraduate research and workshops for faculty members related to undergraduate research topics were the two least popular options. Only $3.5 \%$ of faculty members rated them as a "deal breaker," and nearly $70 \%$ of respondents stated they would not be interested in either of these incentives at all.

Table 6 compares group means of the 13 incentives faculty members categorized based on their funding status, career stage, and discipline. As shown in Table 6, when compared with faculty who had been PIs on NIH/NSF grants, faculty who had never been a PI on an NIH/NSF grant were significantly ( $p$ $<0.05)$ more interested in most of the incentives, including student conference travel funds, faculty conference travel funds, faculty summer stipends, provision of equipment, faculty learning communities, workshops for faculty, workshops for students, reduced service obligations for faculty, reassigned time for faculty (e.g., a course release), teaching credit for faculty, and preresearch training for students. There were no statistically significant differences between the two groups in terms of stipends for undergraduate student researchers and provision of supplies needed for the undergraduate to take part in the research. This is due to the fact that both of the groups were highly interested in these two items.

With regard to career stage, the significance levels of Kruskal-Wallis $H$ tests shown in Table 6 indicate that, across the three groups (i.e., early-career faculty, midcareer faculty, and late-career faculty), there were statistically significant differences in terms of preferences for faculty conference travel funds, faculty summer stipends, provision of equipment, faculty learning communities, workshops for faculty, reduced service obligations for faculty, reassigned time for faculty (e.g., a course release), and teaching credit for faculty. To illustrate how to interpret the results for the post hoc comparisons between groups presented in Table 6, we explain the process in detail by referring to the subscript letters denoted in Table 6 for faculty conference travel funds. Early-career faculty and midcareer faculty both are denoted by the subscript letter "a," meaning there is no statistically significant difference between those two groups. The result for the pairwise comparison between midcareer faculty and late-career faculty indicates a statistically significant difference, since midcareer faculty are denoted with the subscript letter "a," while late-career faculty are denoted with the subscript letter "b." Thus, post hoc testing reveals that late-career faculty were significantly less interested in faculty conference travel funds compared with midcareer faculty and that the level of interest for early-career faculty was not statistically significantly different from midcareer faculty but statistically significantly different from late-career faculty. Readers can employ the same approach to guide their interpretation of results for the other post hoc comparisons. Generally speaking, late-career faculty were much less interested in faculty learning communities and faculty workshops than early-career faculty; late-career faculty were less interested in faculty summer stipends than midcareer faculty; and late-career faculty were less interested 


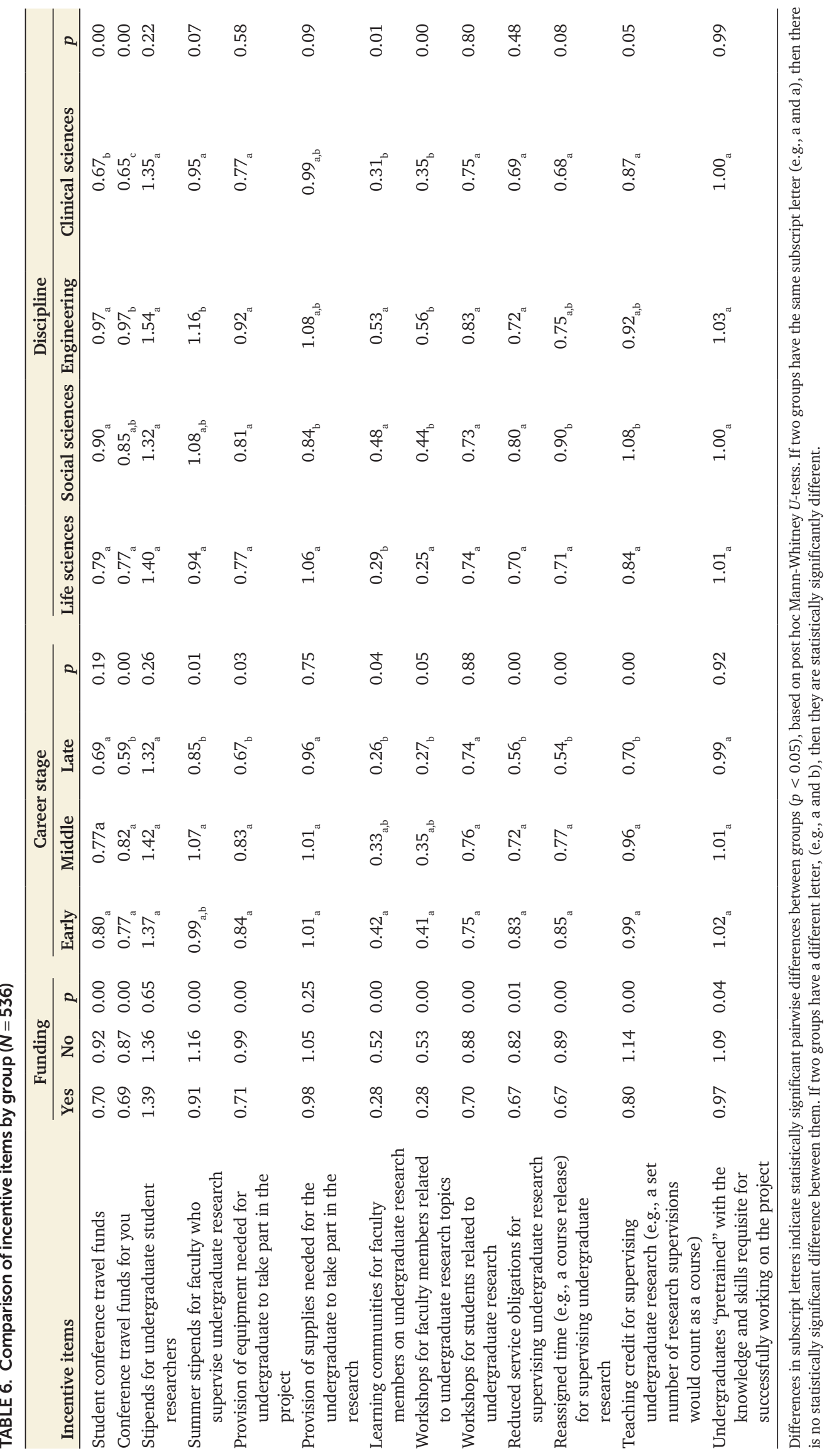


in faculty conference travel funds, provision of equipment, reassigned time for faculty (e.g., a course release), reduced service obligations, and teaching credit than both early-career and midcareer faculty.

With regard to the four different disciplinary areas (life sciences, social sciences, engineering, and clinical sciences), Kruskal-Wallis $H$-test results show that, across the four groups, there were statistically significant differences in terms of student conference travel funds, faculty conference travel funds, faculty learning communities, and faculty workshops. Specifically, post hoc testing revealed that, compared with life sciences, social sciences, or engineering faculty, clinical sciences faculty were much less interested in student conference travel funds and faculty conference travel funds, while engineering faculty were more interested in faculty conference travel funds than life sciences or clinical sciences faculty. Compared with life sciences and clinical sciences faculty, social sciences and engineering faculty were more interested in faculty workshops; additionally, life sciences faculty were significantly less interested in faculty learning communities than faculty in the other three disciplinary areas. Finally, social sciences and engineering faculty indicated greater interest in teaching credit for faculty compared with faculty in the other two disciplinary areas.

\section{DISCUSSION}

In terms of research question 1 , several factors were important in shaping faculty members' willingness to mentor undergraduates from other universities. Faculty who placed greater value on the opportunity to increase diversity in the academy through mentorship of underrepresented minorities were more interested in mentoring undergraduates from another university. This finding aligns with the framework of organizational citizenship theory, which suggests that, if individuals believe roles separate from their prescribed duties are actually integral elements of their work, they will be more likely to voluntarily fulfill those roles (Herzberg, 1966; McManus and Russell, 1997; Judge et al., 2001), and we believe seeking to mentor undergraduate students as a way to increase diversity in the academy qualifies as one of these extra, but integral, roles. A similar connection between the organizational citizenship framework and faculty mentorship can be found in the study by Eagan and colleagues (2011) of faculty motivation to mentor students at their home university. The authors found that faculty who felt more strongly about improving students' "habits of mind for learning" (another extra but integral role of a professor) were more likely to involve undergraduates (from their own institutions) in research. It was notable that the other two dispositional factors were not significant. This may relate to the fact that interinstitutional research training programs are more likely to be 10 -wk summer research programs than longer-term programs. Faculty may think $10 \mathrm{wk}$ is too short a period of time to prepare an undergraduate student from another university for graduate school, for example, and therefore believe such a program would not provide the opportunity to accomplish that goal.

In terms of the two variables related to expected costs and benefits, we found that faculty who agreed more strongly that undergraduate students could contribute to their research were significantly more interested in mentoring an external student from another university via a formal undergraduate research program and that faculty who agreed more strongly that supervising undergraduates was time-consuming were less interested. These findings are interpretable in reference to social exchange theory, specifically the idea that faculty weigh the costs and benefits when deciding whether or not to mentor a student. In this case, the benefits apparently outweigh the costs, with those faculty agreeing more strongly that mentees help them with their research being significantly more likely to express interest in serving as a mentor to a student from another university. These findings can also be connected to other research that has suggested that faculty are more likely to mentor students in general when they see the mentorship as beneficial, although those studies did not specifically focus on the mentorship of summer visiting students (Gibb, 1999; Hegstad, 1999; Chopin, 2002; Webber et al., 2013).

In terms of situational factors, it was not surprising that faculty who believed more strongly that they did not have the ability to accommodate additional students on their research teams were less interested in mentoring visiting students in this undergraduate research program. This is an ongoing challenge for summer programs seeking to place students in already crowded research environments. Faculty who had been a PI on both an NIH and an NSF grant exhibited significantly greater interest in mentoring students from another university through this program, compared with those who had not been a PI on an NIH or NSF grant. A similar association between securing funding for research and greater involvement of undergraduate students in faculty-directed research projects has been found in prior studies conducted within intra-institutional mentoring contexts (Einarson and Clarkberg, 2004; Eagan et al., 2011).

Counterintuitively, results indicated that faculty members who agreed more strongly that their institution's reward structures (e.g., tenure system) were at odds with mentoring were actually more interested in mentoring undergraduates from another university. Results from a similar model predicting interest in mentoring undergraduate from one's home university using the same sample of faculty found the opposite (unpublished data). Others have emphasized that faculty face institutional obstacles in mentoring undergraduate students, because current promotion and tenure systems typically emphasize research productivity over engagement with undergraduate students (O'Meara and Braskamp, 2005). Our finding suggests an important difference in willingness to mentor students from one's home institution versus another institution. Institutional reward systems that do not emphasize mentoring are less of a barrier to faculty interested in working with visiting students over the summer than they are to faculty working with internal students during the academic year. It may be that faculty view mentoring visiting summer students, especially "diversity students" from relatively resource-strapped institutions, as something they should do as good organizational citizens in STEM research fields; their decision to participate may be less related to their universities' institutional reward structures (which typically place far less value on working with students from other institutions than those enrolled in degree programs within one's home university) and more related to their own values and beliefs. The choice to prioritize one's own values may be more common in the summer, which is traditionally a block of time when faculty have fewer structured obligations and may engage 
in professional activities of their own choosing. Faculty may also view visiting undergraduates as prospective graduate students and thus consider them worth engaging for recruitment purposes, even if little immediate value is placed upon mentoring undergraduates in their institutional context.

Previous mentoring experience has been shown to be positively related to future willingness to mentor others (Ragins and Cotton, 1993; Ragins and Scandura, 1999; Allen, 2003; Allen et al., 1997, 2000; Bozionelos, 2004). In our study, mentoring experience was also positively related to faculty interest in mentoring undergraduates; however, the association was not statistically significant. This may be related to the fact that, in our sample, the vast majority of faculty members (93\%) had mentoring experience.

Among the four variables representing demographic factors, career stage was the most important predictor in our model. Midcareer faculty were more interested in mentoring undergraduates from another university than were early- and latestage faculty members. However, male and female faculty, faculty from different racial/ethnic groups, and those from different disciplines were equally interested in mentoring undergraduate students from another university through an interinstitutional research training program. When considering the faculty demographic factors as a group, we found that faculty career-related characteristics were more important predictors than faculty gender or race/ethnicity, as did Eagan et al. (2011). It may seem surprising to some readers that Hispanic faculty were not significantly more motivated than white faculty to accept a student, given the regional focus of BUILDing SCHOLARS and the fact that many of the student mentees are likely to be Hispanic. Our results did suggest that Hispanic faculty were more likely to be interested in mentoring students from another university than were white (non-Hispanic) faculty members, although the finding was not significant. The lack of significance could relate to the small percentage of Hispanic faculty in our sample (17\%). The directionality of this finding may be explained by research demonstrating that faculty of color were more likely to engage in mentoring students, because they viewed mentoring as a way to give back to their community and as a chance to serve as role models (Stanley, 2006; Schwartz, 2012).

To answer research question 2 , we examined faculty preferences for different possible program incentives. The results show that, among the various incentives for faculty participation an interinstitutional research training program could offer, faculty found both student incentives (including summer stipends, research supplies, and preresearch training) and mentor incentives (including summer stipends, teaching credit for mentoring, and equipment) to be highly important. However, most faculty members were not interested in faculty learning communities and faculty workshops. In addition, the importance that faculty ascribe to different types of incentives varied based on career stage, discipline, and funding status. Generally speaking, our findings suggest that social sciences faculty, faculty without experience as NSF or NIH PIs, and faculty at the early-career stage were most likely to be motivated to participate as mentors by program incentives.

In terms of the practical implications from this study, findings are relevant to the design and management of interinstitutional research training programs centered on faculty-mentored stu- dent research experiences. On the basis our findings, we recommend that interinstitutional research programs seeking to incentivize faculty participation provide research skills training to visiting undergraduate students before they engage in faculty-mentored research. When asked about their preferences for incentives, the majority of surveyed faculty (84.6\%) responded that "pretrained students" would be desirable (i.e., a deal breaker or a bonus). The multivariate findings from research question 1 corroborate this. We found that faculty motivation to mentor undergraduate students from other universities was influenced positively by the expected benefit of assistance on projects and negatively by the expected time-cost demands. Better prepared students will be able to more effectively assist their mentors with less remedial guidance, which is critically important in the context of relatively short (i.e., 10 wk or fewer) research experiences. Therefore, if programs provide research skills training for students before they join their faculty in the lab, it stands to reason that mentoring visiting undergraduates will become less of a hindrance and more supportive of faculty members' research productivity. This may be especially important for early-career faculty, who face the time pressure of the tenure clock. Pre-training can be implemented in a variety of ways. Summer programs can adopt apprenticeship or peer-mentoring models in which new student trainees are assigned to more senior students in faculty mentors' research teams in order receive training (Knox et al., 2006; Prince et al., 2007; Lopatto, 2010). The senior students could receive token stipends and teaching skills training through the program. Through UTEP's BUILDing SCHOLARS program, external undergraduate students doing summer research at UTEP are pretrained using a compressed version of an academic-year interdisciplinary research foundations course. The course is team taught by instructors from different disciplines and offered the week before students begin their summer research placements. The course covers research ethics, the scientific method, keeping a laboratory notebook, critical thinking, journaling, and the research cycle.

The results also speak to the importance of utilizing different recruitment strategies to more effectively target faculty mentors at different career stages. Results suggest that what works for attracting senior faculty might be different from what will be most effective for junior faculty. We found that midcareer faculty members were more motivated to serve as mentors than early-career and late-career faculty in our multivariate analysis. It stands to reason, then, that most undergraduate research programs will thrive largely due to the engagement of midcareer faculty as mentors, as these faculty may need less targeted recruitment to become involved. It is important to recognize, however, that early-career and late-career faculty also have much to offer undergraduate researchers. Late-career faculty members tend to have rich research experiences, extensive academic networks, and the drive to solidify their scholarly legacies, which may provide valuable opportunities for undergraduate students. On the other hand, early-career faculty are often more similar in age and share more life experiences with undergraduate students, hence students may identify more closely with early-career faculty as role models (Morrison-Beedy et al., 2001; Rose et al., 2005; Thomas and Gillespie, 2008).

Results of our incentive analysis shed light on possible ways of motivating participation by late- and early-career faculty. Late-career faculty were more interested in incentives related to 
students (e.g., summer stipends for student, research supplies for students, or preresearch training for students) than the benefits they themselves might receive (e.g., reduced service obligations, course releases, or conference travel funds). In contrast, early-career faculty were interested in incentives for both themselves and their students. They were especially interested in institutional support for mentoring, including reduced service obligations, reassigned time, and teaching credits. Therefore, depending on the needs of a program and what incentives are available, this information can be used to target mentor-recruitment efforts.

Results suggest that faculty members with experience as PIs of externally funded research projects are motivated to participate as mentors for visiting students and that engaging nonfunded mentors will require the outlay of more programmatic resources. Incentive analysis results demonstrated that faculty without funding desired more program incentives than funded faculty. This suggests that programs operating at universities without many grant-funded faculty and those interested in placing students with early-career professors who are less likely to have PI experience (in our sample, $48.9 \%$ of the early-career faculty had PI experience compared with $87.1 \%$ of the late-career faculty) may need to offer more incentives to recruit faculty mentors. When faculty are interested but do not have enough resources of their own, programmatic resources can offer particularly powerful incentives.

Finally, our results suggest that promoting faculty awareness of the positive impacts of mentored research training on underrepresented minority students could be an effective recruitment tool. Specifically, we found that faculty who placed greater value on the opportunity to increase diversity in the academy through mentorship of underrepresented minorities were more willing to mentor external students than were those who valued that opportunity less. Therefore, it stands to reason that information campaigns highlighting findings from research studies demonstrating the benefits of undergraduate research experiences for underrepresented minority students might increase faculty willingness to engage in mentoring relationships with visiting students from underrepresented backgrounds and/or underresourced institutions (e.g., community colleges).

\section{CONCLUSION}

The United States is currently seeing growth in interinstitutional research training programs; one example is the $\sim \$ 31$ million NIH is currently investing in the 10 BUILD sites each year starting in 2014-2015. Within the BUILD program alone, there is demand for hundreds of faculty members to serve as mentors of scholarship students, and this is just one mechanism. Other programs, like NSF Research Experience for Undergraduates sites, also recruit visiting student participants. This growth in training programs is occurring in an era in which tenure is declining in higher education across the country: while more than $78.3 \%$ of faculty held tenure-track or tenured positions nationally in 1969 , only $33.5 \%$ did so by 2009 , according to a report published by the Association of Governing Boards of Universities and Colleges (Kezar and Maxey, 2013). While most faculty in this sample were interested in mentoring, we expect that it will become more difficult to recruit and retain faculty mentors over time. In our survey, fewer faculty were interested in mentoring a visiting student than a student from their home institution (74\% vs. 85\%), suggesting that interinstitutional research training programs may face more faculty-recruitment challenges than internal programs.

Our analysis did suggest that faculty members can reach a saturation point and no longer be able to accept additional students; faculty who did not have the ability to accommodate additional students on their research teams were significantly less interested in mentoring external students. This suggests that funding to offer programmatic incentives to reward faculty mentors in meaningful ways is paramount to program success and that there is a need for more information about undergraduate research experiences from faculty mentors' perspectives. Future research could extend this line of inquiry by conducting cost-benefit analyses of faculty decisions to mentor undergraduate students, by clarifying characteristics of the most effective undergraduate research mentors, and by examining determinants of successful research outcomes (e.g., coauthored papers) associated with mentoring undergraduate students.

\section{ACKNOWLEDGMENTS}

We acknowledge our research team, which includes Heather Daniels, Gabrielle Mendoza, and Angela Frederick, and the faculty members who participated in the survey. Research reported in this publication was supported by the National Institute on Minority Health and Health Disparities of the NIH under award number P20MD008700. We also thank the NIH Diversity Program Consortium for support through BUILD award numbers 8RL5GM118969-02 (D.X.M. and S.E.G.) and 8UL1GM118970-02 (T.W.C.). The content is solely the responsibility of the authors and does not necessarily represent the official views of the NIH.

\section{REFERENCES}

Aagaard EM, Hauer KE (2003). A cross-sectional descriptive study of mentoring relationships formed by medical students. J Gen Intern Med 18, 298-302.

Alexander B, Foertsch J, Daffinrud S, Tapia R (2000). The "Spend a Summer with a Scientist" (SaS) program at Rice University: a study of program outcomes and essential elements 1991-1997. Counc Undergrad Res Q 20, 127-133

Allen TD (2003). Mentoring others: a dispositional and motivational approach. J Vocat Behav 62, 134-154

Allen TD (2007). Mentoring relationships from the perspective of the mentor In: The Handbook of Mentoring at Work: Theory, Research, and Practice, ed. BR Ragins and KE Kram, Thousand Oaks, CA: Sage, 123-147.

Allen TD, Poteet ML, Burroughs SM (1997). The mentor's perspective: a qualitative inquiry and future research agenda. Vocat Behav 51, 70-89.

Allen TD, Poteet ML, Russell JEA (2000). Protégé selection by mentors: what makes the difference? J Organ Behav 21, 271-282.

Allison P (2005). Imputation of categorical variables with PROC MI. SUGI 30 Proceedings paper 113-30,1-14. www2.sas.com/proceedings/sugi30/ 113-30.pdf (accessed 16 July 2015)

Antonio AL (2002). Faculty of color reconsidered: reassessing contributions to scholarship. J High Educ 73, 582-602

Aryee S, Chay YW, Chew J (1996). The motivation to mentor among managerial employees in the maintenance career stage: an interactionist's perspective. Group Organ Manage 21, 261-277.

Bauer KW, Bennett JS (2003). Alumni perceptions on the value of undergraduate research. J High Educ 74, 210-230.

Bauer KW, Bennett JS (2008). Evaluation of the undergraduate research program at the University of Delaware: a multifaceted design. In: Creating 
Effective Undergraduate Research Programs in Science: The Transformation from Student to Scientist, ed. R Taraban and RL Blanton, New York: Teachers College Press.

Bellas M, Toutkoushian R (1999). Faculty time allocations and research productivity: gender, race and family effects. Rev High Ed 22, 367-390.

Belsley D, Kuh E, Welsch R (1980). Regression diagnostics: identifying influential data and sources of collinearity. Hoboken, NJ: Wiley.

Boyle P, Boice B (1998). Systematic mentoring for new faculty teachers and graduate teaching assistants. Innov High Educ 22, 157-179.

Bozionelos N (2004). Mentoring provided: relation to mentor's career success, personality, and mentoring received. J Vocat Behav 64, 24-46.

Brown MC II, Davis GL, McClendon SA (1999). Mentoring graduate students of color: myths, models, and modes. Peabody J Educ 74, 105-118.

Burnley PC, Evans W, Jarrett OS (2002). A comparison of approaches and instruments for evaluating a geological sciences research experiences program. J Geosci Educ 50, 15-24.

Butler PJ, Dong C, Snyder AJ, Jones AD, Sheets ED (2008). Bioengineering and Bioinformatics Summer Institutes: meeting modern challenges in undergraduate summer research. CBE Life Sci Educ 7, 45-53.

Campbell TA, Campbell DE (1997). Faculty/student mentor program: effects on academic performance and retention. Res High Educ 38, 727-742.

Chopin SF (2002). Undergraduate research experiences: the transformation of science education from reading to doing. Anat Rec 269, 3-10.

Cole D, Espinoza A (2008). Examining the academic success of Latino students in science technology engineering and mathematics (STEM) majors. J Coll Stud Dev 49, 285-300.

Cronan-Hillix T, Davidson WS, Cronan-Hillix WA, Gensheimer LK (1986). Student's views of mentors in psychology graduate training. Teach Psychol 13, 123-127.

Dalton GW, Thompson PH, Price RL (1977). The four stages of professional careers: a new look at performance by professionals. Organ Dynamics 6(2), 19-42.

Dunham-Taylor J, Lynn CW, Moore P, McDaniel S, Walker JK (2008). What goes around comes around: improving faculty retention through more effective mentoring. J Prof Nurs 24, 337-346.

Eagan K, Sharkness J, Hurtado S, Mosqueda C, Chang M (2011). Engaging undergraduates in science research: not just about faculty willingness. Res High Educ 52, 151-177.

Einarson M, Clarkberg M (2004). Understanding Faculty Out-of-Class Interaction with Undergraduate Students at a Research University, Ithaca, NY: Cornell Higher Education Research Institute, Cornell University.

Emerson RM (1981). Social exchange theory. In: Social Psychology: Sociological Perspectives, ed. M Rosenberg and RH Turner, New York: Basic, $30-65$.

Enders CK (2010). Applied Missing Data Analysis, New York: Guilford.

Espinosa $L$ (2011). Pipelines and pathways: women of color in undergraduate STEM majors and the college experiences that contribute to persistence. Harvard Educ Rev 81, 209-241.

Falconer J, Holcomb D (2008). Understanding undergraduate research experiences from the student perspective: a phenomenological study of a summer student research program. Coll Stud J 42, 869-878.

Finley A, McNair T (2013). Assessing Underserved Students' Engagement in High-Impact Practices, Washington, DC: Association of College and Universities.

Foertsch JA, Alexander BB, Penberthy DL (1997). Evaluation of UW-Madison's Summer Research Programs, Madison, WI: Lead Center.

Frantz KJ, DeHaan RL, Demetrikopoulos MK, Carruth LL (2006). Routes to research for novice undergraduate neuroscientists. Cell Biol Educ 5, 175-187.

Garson G (2012). Generalized Linear Models and Generalized Estimating Equations, Asheboro, NC: Statistical Associates Publishing.

Gates AQ, Teller P, Bernat A, Delgado N, Della-Piana C (1999). Expanding participation in undergraduate research using the affinity group model. $J$ Eng Educ 88, 409-414.

Gibb S (1999). The usefulness of theory: a case study in evaluating formal mentoring schemes. Hum Relat 52, 1055-1075.
Gum A, Mueller K, Flink D, Siraj S, Batsche C, Boothroyd R, Stiles P (2007). Evaluation of a summer research institute in behavioral health for undergraduate students. J Behav Health Serv Res 34, 206-218.

Hathaway RS, Nagda B, Gregerman S (2002). The relationship of undergraduate research participation to graduate and professional education pursuit: an empirical study. J Coll Stud Dev 43, 614-631.

Hegstad CD (1999). Formal mentoring as a strategy for human resource development: a review of research. Hum Res Dev Q 10(A), 383-390.

Herzberg F (1966). Work and the Nature of Man, Cleveland, OH: World.

Hill SE, Bahniuk MH, Dobos J, Rouner D (1989). Mentoring and other communication support in the academic setting. Group Organ Stud 14, 355-368.

Horton N, Lipsitz S, Parzen M (2003). A potential for bias when rounding in multiple imputation. Am Stat 57, 229-232.

Hunter AB, Laursen S, Seymour E (2007). Becoming a scientist: the role of undergraduate research in students' cognitive, personal, and professional development. Sci Educ 91, 36-74.

Hunter VJ (2002). Mentoring: the forgotten retention tool. Black Issues High Educ 19, 18-49.

Ishiyama J (2002). Does early participation in undergraduate research benefit social science and humanities majors? J Coll Stud Dev 36, 380 386.

Johnson WB (2002). The intentional mentor: strategies and guidelines for the practice of mentoring. Prof Psychol Res Pract 33, 88-96.

Judge TA, Bono JE, Thoresen CJ, Patton GK (2001). The job satisfaction-job performance relationships: a qualitative and quantitative review. Psychol Bull 127, 376-407.

Kardash CA (2000). Evaluation of an undergraduate research experience: perceptions of undergraduate interns and their faculty mentors. J Educ Psychol 92, 191-201.

Kezar A, Maxey D (2013). The Changing Academic Workforce. Trusteeship 21(3), 15-21.

Knox S, Schlosser LZ, Pruitt NT, Hill CE (2006). A qualitative examination of graduate advising relationships: the advisor perspective. Couns Psychol 34, 489-518.

Kremer JF, Bringle RG (1990). The effects of an intensive research experience on the career of talented undergraduates. J Res Dev Educ 24, 1-5.

Kuh G, Chen D, Laird TF (2007). Why teacher-scholars matter: some insights from FSSE and NSSE. Liberal Educ 93, 40-45

Laursen S, Hunter AB, Seymour E, Thiry H, Melton G (2010). Undergraduate Research in the Sciences: Engaging Students in Real Science, San Francisco: Jossey-Bass.

Lawler EJ, Thye SR (1999). Bringing emotions into social exchange theory. Annu Rev Sociol 25, 217-244.

Levinson DJ (1978). Seasons of a Man's Life, New York: Academic.

Lopatto D (2004). Survey of undergraduate research experience (SURE): first findings. Cell Biol Educ 3, 270-277.

Lopatto D (2010). Undergraduate research as a high-impact experience. Peer Rev 12, 27-30.

Luna G, Gullen D (1995). Empowering the Faculty: Mentoring Revisited and Renewed, ASHE-ERIC Higher Education Report No. 3, Washington, DC: George Washington University, Graduate School of Education and Human Development.

McManus SE, Russell JEA (1997). New directions for mentoring research: an examination of related constructs. J Vocat Behav 51, 145-161.

Merkel CA (2001). Undergraduate Research at Six Research Universities: A Pilot Study for the Association of American Universities, Pasadena: California Institute of Technology.

Morrison-Beedy D, Aronowitz T, Dyne J, Mkandawire L (2001). Mentoring students and junior faculty in faculty research: a win-win scenario. J Prof Nurs 17, 291-296.

Nagda BA, Gregerman SR, Jonides J, von Hippel W, Lerner JS (1998). Undergraduate student-faculty research partnerships affect student retention. Rev High Ed 22, 55-72.

Nelder JA, Wedderburn RWM (1972). Generalized linear models. J R Stat Soc Ser A $135,370-384$ 
O'Meara KA, Braskamp L (2005). Aligning faculty reward systems and development to promote faculty and student growth. NASPA J 42, $223-$ 240.

Pike GR, Kuh GD (2005). First- and second-generation college students: a comparison of their engagement and intellectual development. J High Educ 76, 276-300.

Prince M, Felder R, Brent R (2007). Does faculty research improve undergraduate teaching? An analysis of existing and potential synergies. J Eng Educ 96, 283-294.

Ragins BR, Cotton JL (1993). Gender and willingness to mentor in organizations. J Manage 19, 97-111.

Ragins BR, Scandura TA (1999). Burden or blessing? Expected costs and benefits of being a mentor. J Organ Behav 20, 493-509.

Raudenbush SW, Bryk AS (2002). Hierarchical Linear Models: Applications and Data Analysis Methods, Thousand Oaks, CA: Sage.

Rodwell L, Lee K, Romaniuk H, Carlin J (2014). Comparison of methods for imputing limited-range variables: a simulation study. BMC Med Res Methodol 14, 57

Rose GL, Rukstalis MR, Schuckit MA (2005). Informal mentoring between faculty and medical students. Acad Med 80, 344-348.

Russell SH (2008). Undergraduate research opportunities: facilitating and encouraging the transition from student to scientist. In: Creating Effective Undergraduate Research Programs in Science: The Transformation from Student to Scientist, ed. R Taraban and RL Blanton, New York: Teachers College Press, Columbia University, 53-80.

Schowen B (2002). Value and impact of undergraduate research in chemistry: lessons gained from 45 years of experience at the University of Kansas. ConfChem Conference on Undergraduate Research, held April 17-18, 2002, in Lawrence, KS

Schwartz J (2012). Faculty as undergraduate research mentors for students of color: taking into account the costs. Sci Educ 96, 527-542.
Seymour E, Hunter A, Laursen SL, Deantoni T (2004). Establishing the benefits of research experiences for undergraduates in the sciences: first findings from a three-year study. Sci Educ 88, 493-534.

Stanley CA (2006). Coloring the academic landscape: faculty of color breaking the silence in predominantly white colleges and universities. Am Educ Res J 43, 701-736.

Stromei LK (2000). Increasing retention and success through mentoring New Dir Commun Coll 112, 55-62.

Thomas E, Gillespie D (2008). Weaving together undergraduate research: mentoring of junior faculty, and assessment: the case of an interdisciplinary program. Innov High Educ 33, 29-38.

Tompkins L (1998). Being a scientist: one woman's experience. In: Women in Science: Meeting Career Challenges, ed. A Pattarucci, Thousand Oaks, CA: Sage, 110-115.

UTEP (University of Texas at El Paso), CIERP (Center for Institutional Evaluation Research and Planning) (2013). The UTEP 2012-2013 fact book. http://irp.utep.edu/LinkClick.aspx?link = Fact + Book +2012-13 pdf\&tabid=29986\& mid $=62808$ (accessed 2 July 2014).

Volkwein F, Carbone D (1994). The impact of departmental research and teaching climates on undergraduate growth and satisfaction. J High Educ 65, 147-167

Wasserman ER (2000). The Door in the Dream: Conversations with Eminent Women in Science, Washington, DC: Joseph Henry Press.

Webber KL, Nelson Laird TF, BrckaLorenz AM (2013). Student and faculty member engagement in undergraduate research. Res High Educ 54, 227-249.

Zellers DF, Howard VM, Barcic MA (2008). Faculty mentoring programs: reenvisioning rather than reinventing the wheel. Rev Educ Res 78, 552-588.

Zydney AL, Bennett JS, Shahid A, Bauer KW (2002). Faculty perspectives regarding the undergraduate research experience in science and engineering. J Eng Educ 91, 291-297. 